\title{
Creative and cultural industries in Europe - case study of the performing arts in Romania
}

\author{
Iuliana CETINĂ \\ Academy of Economic Studies, Bucharest, Romania \\ Iuliana.cetina@mk.ase.ro \\ Andrei L. BĂDIN \\ Academy of Economic Studies, Bucharest, Romania \\ Andrei.badin@mk.ase.ro
}

\begin{abstract}
Culture is one of the most important aspects of being human alongside education. A very interesting way of approaching the issue of culture is understanding the importance of the art in everyday life. Alan Peacock, one the first pioneers of the term cultural economy, was a man of the arts who understood the importance of culture, not only in life, but in economy. Many writers in the 1960s identified some opportunities in engaging in the cultural and arts industries. As we know, cultural goods have an economic value and an artistic value. The evaluation of artistic goods or products is made only after it is consumed by clients or customers. The world of cultural services is large and forgiving with non-professionals. The use of cultural policies in today's European Union, United States of America and Asia is very important because of the positive spillover it causes. Creating cultural policies and dedicating funds specifically for this started in the 1980s with the implication of UNESCO. Cultural policies not only help preserve cultural sites and heritage, but offers a broader strategy that envelops both cultural goods and cultural services. The cultural marketing concept refers to the art of using marketing tactics and strategies in order to promote and develop the cultural and artistic industries or sectors. The same instruments are used but the way in which they are used is very different. The performing arts sector is ever changing and it needs a new marketing mix approach to connect to new audiences. Artists need to work closely with business and management professionals in order to have the best representation off stage.
\end{abstract}

Keywords: cultural marketing, economy of arts, marketing mix, cultural policy, cultural services.

\section{Introduction}

The creative industries continue to improve and benefit the general population with help from new technological advances like big data, software`s, social media, algorithms and predictability, data mining and so on.

It is very hard to evaluate the creative industry. First and foremost it is difficult to apply economic theories in some creative industries mainly because of an internal resistance. Many artists, not all, see art not like a business or a corporation, but as a living and breathing entity that evolves by its own volition. This is true, but surely marketing, management and economics can improve some of the processes and flows that exist between art and public. This is one part of the hypothesis, in which the artist, the creator, is unwilling to change or see the benefits of adopting a strategy. The second part of the hypothesis is that in which we find artist that really commit to marketing and management professionals as 
well as try and perfect their art by adopting a customer centric strategy. As well, we can find artist that are in the middle and require some convincing.

There are many other creative industries, but the purpose of this article is to explore solely the relationship between the performing arts and marketing theory. As well, we analyze the "status-quo" in the performing arts industries. Through our analysis we use Eurostat data to see a real representation of the artistic movement in the European Union. The second part is the analysis of internal data seen from the National Institute of Statistics in Romania. The objective of this analysis is to observe the development of the performing arts industry at a national and European level.

It is very important to understand how the creative industries work and how they developed throughout the years. The ESSnet-Culture framework covers cultural statistics from defined domains: heritage, archives, libraries, books and press, visual arts, performing arts, audio-visual and multimedia, architecture, advertising and art crafts (Eurostat, 2018). In 2018 we see an increase in artistic occupations.

Culture consumption is growing. Together with UNESCO, the European Union special cultural council offers the possibility for culture to grow and penetrate other markets than the local ones. More and more artists are orienting themselves to online and digital technologies. This as well is something that UNESCO is trying to implement in their cultural policy (UNESCO, 2018), as well as the E.U. council (Eurostat, 2018). It is very interesting to see how member states improve and grow their culture consumption from year to year; of course this is dependent both on cultural strategy and policy, as well as the openness of the country towards accessing European Union funds for developing cultural products and services. At the moment, Romania is on a positive trend in the performing arts sector.

In the last 10 years the cultural and creative industries have been broadening the cultural policy scope and perfecting the way in which different components of this cultural ecosystem coexist, interact and relate with economy and society (UNESCO, 2018). It is very interesting seeing how the digital technologies have changed the way in which the creative industries and art creating have changed because before there was a process from start to finish, a pipeline model (UNESCO, 2018), but now we can observe a new network model in which everything is linked to everything (UNESCO, 2018). This offers the possibility to increase the engagement of the public not only with the final product or service, but engage and influence the making of a certain product or service.

Cultural policy is very important for a country because this is a macroeconomic strategy that helps and contributes to the development and evolution of the creative industry. Multilevel governance means that the direction painted by the Ministry of Culture must be implemented and promoted by the smallest form of public administration in any region of the country, with the allocated budget and making use of all their competences. The strategies used must integrate every cultural element that the country has in order to promote them for national and international awareness (UNESCO, 2018).

We can observe in Romania, starting with the year 2014 that the number of specialized locations that offer performing arts services reached 254 (Iagăr et all, 2016). By comparison, in the years 2014 and 2015 we can see a slight increase of under $10 \%$ in total number of artistic, performing arts and concerts institutions. The number of artistic representations has also increased from 15956 in 2014 to 19.020 in 2015. The number of plays also increased but not as much from 20786 in 2014 to 22538 in 2015. 
The evaluation of spectators is dependent on the type of performance offered by various forms of cultural institutions. The year 2015 got an increase in spectators by 12,3\% in the theater performance and a decrease of $13,7 \%$ in the dance and artistic ensembles performances (Iagăr et all, 2016). Most of the artistic institutions are in Bucharest, over 45 entities (Iagăr et all, 2016). The most representations have been in Bucharest, over 6250 performances and the most spectators, over 1,3 million.

Comparing the year 2016 with 2015, we can see a decrease in artistic and cultural venues, from 254 in 2015 to 227 in 2016 (Iagăr et all, 2017). In the year 2016 compared with 2015 we can observe a decrease of overall events (Iagăr et all, 2017). As well, the number of representations has declined a little bit from 22538 to 22356 . The number of spectators has remained approximately the same, over 5,5 million (Iagăr et all, 2017).

A constant is the amount of interested consumers in theater, it is still the preferred artistic performance (41,7\% of the total performance art public), but it is lower than in 2015 by $1,1 \%$ (26000 spectators). As well, the dance and entertainment performances have decreased by 4,7\% (87000 spectators) in 2016 (Iagăr et all, 2017).

In the year 2017 we can see (INS, 2018) a slightly growing tendency 230 artistic institutions, 3 more than in 2016. In the year 2017 more than 6,4 million spectators have engaged with artistic performances (INS, 2018), this represents approximately 1 million spectators more in the course of one year.

The interest in theater is still constant, most spectators partaking in theater performances, $42 \%$, while $32,2 \%$ in dance and other entertainment performances.

\section{Literature review}

The concept of cultural industries revolves around five main criteria: creativity, intellectual property, symbolic meaning, use value and methods of production (Gallow \& Dunlop, 2007). It is very interesting that the cultural industries and creative industries are one and the same for most people (Cunningham in Gallow \& Dunlop, 2007). One interesting approach to the history of the terms cultural industries and creative industries is analyzing the essence of each one. The development of the digital environment has managed to increase the potency of the cultural industries from the old days, one argument is that the technological advances made room and broadened the definition of cultural industries, transforming it in the creative industries (Cunningham in Gallow \& Dunlop, 2007). These changes affect also the cultural policy making, strategies that 20 or 30 years ago worked, now they have to be reshaped and implemented with the help of new technologies.

The knowledge economy affects and is affected by the creative industries in a way in which, cultural or creative industries, or even the process of producing a cultural good is assimilated to the knowledge economy.

The topic of creative industries is strongly related to cultural economics. Alan Peacock is a pioneer in cultural economics and one of the most outstanding personalities that contributed to this topic for more than 40 years (Rizzo \& Towse, 2015). Using economy principles in the creative arts is delicate, the relationship between artists - art - economy professionals is thin because in most cases (as discussed in the introduction) artists feel that any marketing or economy perspective would negate the intended effect of their art on the public. 
The knowledge economy is increasing not only in quantity, but in quality. The creative industries are producing a lot of cultural goods and services. The standard economic approach is rather unsavory to creative people (Graca in Klamer, 2016). A very interesting proposition by Klamer is a value-based approach, this means that the artistic service or product begins with artistic needed values. There are many motives that fuel the creation of art, but some reasons concern the artists life or values, others can be purely money related or even social values (Klamer, 2016). Overall, the values of a cultural product or services are artistic when the creator cares more about making art, everything else is just background noise. Economic valorization is very important, making the creative product or service a commodity (Klamer, 2016), but this is not the main goal. The main goal is to push the artistic value through economic means.

One very interesting approach to the knowledge economy, by consequence the creative or cultural industries, is the cultural spillover. This spillover represents the economic added value generated by cultural goods (art services or products). Many times, the impact is not really expected, but sometimes it is thought about and programmed specifically for a certain impact (Vickery, 2015). Positive spillover from the creative industries can be used for other industries as well: tourism can gain a lot more traction a visibility when paired up with a creative event like Untold festival and the increase of tourists in Ardeal region in Romania, especially Cluj.

Cultural policy is a way in which economic principles can be applied in order to reach cultural objectives and gain economic growth at the same time (Thorsby, 2010). The economic value of culture is dynamic and complex, and it cannot be measured by any standard means (Thorsby, 2010) and this is why creative industry professionals need to focus on qualitative data, social media noise and make use of the artist's value in order to promote them through all existent means, especially the digital environment.

Romania has a very interesting cultural policy that bases its director on the European Union and UNESCO standards and strategies. A very interesting approach of the policy is not to build a hierarchy relationship between cultural goods or services, but a symbiotic one that will work together on all levels (Mucică, et all, 2014).

Cultural policy is used in order to achieve established goals by government, even achieve a positive cultural spillover in other industries like tourism, overall business and even cultural export. Before the $21^{\text {st }}$ century the television, radio, newspapers and outdoor publicity were the main ways in which cultural goods or services were promoted. As Klamer discussed in one of his articles, subsidizing was a way in which the government stimulated cultural consumption. The main reason for stimulating cultural consumption is a consequence of a good learning system that evolves with every generation. After the 1990, the Internet was used to communicate. The business model for the internet is very simple: running ads to potential customers. This new way of promoting products and services is used right now with even more success than before. The digital era changed the business strategy of many industries, but even more so the creative industry. A strategy that could be used especially in the creative industries is convergence, meaning that separate industries or even distinct actions that would have never existed in two or more industries because they are industry specific, now they can benefit one or more industries (Keegan \& Green, 2017). The creative industries are not only in charge of selling a product or service, but an experience. Through the power of the digital environment, companies can engage with their public and try and understand their needs. Any know-how from any industry can help in the search of 
establishing a clear set of goals and strategies to reach the necessary market segment. Convergence is not just a theoretical concept, but a very practical one that is used alongside multidisciplinary and interdisciplinarity especially when talking about cultural goods or services. All businesses are online and they changed radically their business proposition from price-centric approach, towards a customer-centric approach with emphasis on experience and being part of a larger group of people with common values and ideals.

PICBE | 220

Culture participation is growing mainly due to the fast access to anything on the internet. The digital environment is growing from year to year by approximately $1.2 \%$ since 2003 (Groene \& Acker, 2015) and culture consumers are willing to pay for art content more and more.

\section{Marketing the performing arts}

The marketing theory on the creative industries has changed and developed in the last years mainly by trying to explain how traditional marketing efforts could better develop a cultural product or service (Flories et. all, 2010). Using marketing principles, strategies and theories was not just about promotion or establishing a price, but add value to the construction of said cultural product or service (Flories et. all, 2010). Towards this idea there are two main areas of discussion:

1. Never use marketing before the product has been designed by the artist. This means automatically that the consumer's opinion is not taken into account. We could say that this approach is product or service centric. (Colbert \& Cuadrado in Flories et. all, 2010).

This lack of use of marketing means that absolutely no market or consumer needs are identified, and the product is just a materialization of the artist's ideas, concepts and thinking with (little to none) regard to the actual needs of the public. The artists can identify needs, wants, and problems in society, generally elements that they critique or want to address with the help of their art, by no means are they blind or deaf to some ideas or opinions from the public. But it is not enough.

2. Use marketing before, during and after the product or service creation with some limits and boundaries (Solomon in Flories et. all, 2010).

The model for traditional marketing employs four very important elements (Colbert \& Cuadrado in Flories et. all, 2010): the organization, informational system, marketing mix and the market. This model is rather simplistic and may not be what is needed in the creative or cultural industry. The process of creating a cultural good or service is firstly to have the product, as we mentioned above product centric strategy. The second is to see a potential market and after that determine the marketing mix elements: price, distribution, communication and placement.

The model developed by Colbert and Cuadrado in 2003 is product or service oriented. While the artist is working on perfecting the art, they use marketing instruments and strategies for a better understanding of the market, the needs and motives of the customer, how they can satisfy their needs better and offer an improved creative product (Flories et. all, 2010).

A very interesting approach to the creative industries and the use of marketing in the performing arts is that in this industry there is no product centric or customer centric strategy. The main reason is that a balance is needed for artist and public that benefits both, and grow codependent (Scheff \& Kotler, 1996). There are many motives that go into the making of a creative product and a lot of introspection. The work of the artist is not 
independent of a market perspective and this is why marketing efforts in the performing arts has to be a hybrid strategy, an equal collaboration from the artist and the marketing professional.

Marketing efforts can be made while the artistic product is being developed. Solomon gives an idea related to this effort and talks about three subsystems that can help the way in which the creative and marketing endeavors can live together: creative subsystem, PICBE | 221 management subsystem and communication subsystem (Solomon in Flories et. all, 2010).

Another opinion is that the cultural product or service has a very high add value from the consumer and it cannot achieve its true potential without a very strong relationship between artist and market (Boorsma in Flories et. all, 2010).

A very important fact is when the artist finishes a cultural product or service of whatever nature it is just a product or a service. If this product or service achieves the status of art it is fully dependent on the interaction with the public. In other words, the interaction between product and public gives it notoriety and value. Without this interaction, there would be no art. This is why artists should focus on obtaining a lot of information with the help of marketing from their public so that they can achieve their true potential when construction an artistic product or service. The consumer becomes a co-creator of art (Flories et. all, 2010). The main marketing objective is to co-create a unique experience for the public during the consumption of the product or service (Flories et. all, 2010).

There are a lot of ways in which the performing arts product or service can be promoted and even constructed. Following on the idea of the last paragraph, artists make use of the digital environment in order to interact with their public much more easily and freely. The digital platform allows consumers and creators to interact, but it also creates a much more interesting relationship based on co-creation. Using social media and other digital platforms allows artists to engage with consumers instantly. As well, consumers have the opportunity to create alongside their artists (Groene and Acker, 2015). People from around the world have different cultural backgrounds, different educations and different lifestyles so some creative products or services can and should be adapted to address that cultural difference (Blythe, 2005). This helps performing arts endeavors to promote and communicate better, even improve the already existing marketing mix to add more variables that can benefit both consumers and artist. Identifying the expectations from the public is very important in order to address them, maybe even surpass them if it is possible. It is not always good to have a customer centric strategy, but it helps build a relationship with the public (Kotler \& Armstrong, 2017). Potential clients can be identified through market research. The level of satisfaction that is expected by consumers should be surpassed. Establishing this level of satisfaction is very important in order to create a loyal customer that will not only repeat the experience, but will communicate it to his peers (Jimenes and Gervilla, 2011). It is very important to know that there are two kinds of consumers: omnivores that are interested in a large variety of cultural services and carnivores that are only concentrating on a certain kind of artistic service (Paterson in Thorsby, 2010).

Companies in the creative industries use marketing strategies and principles in order to improve their market reach and increase their profit.

The marketing services mix is based on product, price, place, promotion and people (Kotler, 2011). These five elements are the most important in creating a marketing strategy. The internet through which professionals can get in contact and collaborate on projects or with consumers through social media is an environment that can change the marketing mix 
elements and a digital marketing mix can be different from a traditional one (Chaffey and Ellis-Chadwick, 2016). The impact in the digital environment can be positive or negative. The positive aspects are that consumers post their own preferences and data willingly, there is no need to do an actual research. Of course, it is best to have recurrent market research going own to identify new tendencies, likes and dislikes from your target audience, but it is much easier to identify new segments of consumers based on their consumer profile, age, sex, localization etc.

The creative industries can have products or services that can be bought by consumers. In the performing arts we talk about a service that is realized in the presence of the consumer and only then it takes the form of art. Any form of art is not art if it is not in contact with the public, the actual contact gives the creative piece artistic valences. We already see a co-dependence between artist and public, a symbiotic relationship that improves the experience for the public and offers more insight to the artist into motives and expectations of his public (Flories et. all, 2010).

One aspect when talking about price is that in the performing arts we have two areas that should be discussed and taken into consideration. Of course, we establish the price by seeing all our costs. The two areas represent two center costs, production and promotion. In the production we talk about everything that is involved with producing the artistic service, technical necessities, scenography, everything. On the promotion side we talk about the artistic management, marketing efforts and calculating the rentability of the event. The marketing will help a lot the production of the artistic endeavor, but the cost should be separate. After all the costs are on the line, the artistic manager should establish the ticket prices. Discounts can be made in order to gain loyalty (Chaffey and Ellis-Chadwick, 2016). Many times the prices are emotional because the consumer will pay more to partake in a certain event. For example, many consumers will pay extra to see the Vienna Orchestra Show on New Year's Eve because of the moment, even though the same concert can be seen in any other time of the year - the music is the same.

The place where the service takes place is important because it has an impact over the public. In a situation, a certain venue can give the spectators a certain feeling. In other situations the venue can be selected to be cost efficient and generate more profit.

At the moment the most used methods of promotion for the performing arts industry are: outdoor signs, radio shows, television shows, partnerships with media trusts or companies that support the artist in exchange for publicity (barter) and online campaigns. Online campaigns are made through social media platforms that help the online marketer to better identify the target audience and promote the service. As well, Google has a way in which companies can promote their products or services, but through social media the company can give feedback instantly to any customer or potential customer that interacts with it (Chaffey and Ellis-Chadwick, 2016)

Customer satisfaction is achieved by having professional personnel that create an experience for the customer, from start to finish. The objective is to gain a loyal customer that will repeat the buy.

\section{Case Study Performing Arts Romania}

The performing arts industry in Romania is booming. Many concerts and festivals take place in Romania and they attract many tourists from around the world: Untold, Neversea, Garana, George Enescu Festival and many, many others. 
By observing the Untold festival in Cluj, we can see that in the past five years, the local government has invested a lot in infrastructure and overall city development. Having this big festival is one of the big reasons why, because big festivals attract big numbers of tourists that will visit the city in any time of year. Receiving thousands of tourists means a high demand in services and a very high impact on local infrastructure, thus the need for improvement of streets, highways, local transportation etc. Cluj is a very good example of how the creative industry managed to improve the city's overall existence - cultural spillover.

The case study that we propose is about a well-known and well-rounded artist that offers a very interesting service to his audience. He is a prominent figure on the artistic stage of Romania for the last ten years. The musical zones that he engages with are traditional, classical, jazz and rock. Most of his music is composed by him, but he also likes to take old, traditional and folk Romanian music and adapt it so that younger generations can relate to it. The verses never suffer modifications, only slightly, but the music is rearranged in a way in which it speaks to people. Music is a universal language and it communicates much deeper meanings than just words.

\section{Strategy}

The strategy that his management team uses is a hybrid centered between customers and the service provided. The artist is very people oriented, he is an extrovert and he deeply cares about his connection with the audience. As well, the artist understands that he has to be honest about his art and only offer the best possible service to his audience.

His management team understands the fact that there should be more interaction with his public and that is why they create opportunities for the artist to be on live television or on radio shows or a guest speaker at different events. One very important aspect is the equilibrium that the management team gives the artist when creating or thinking about improving an existent cultural service that he provides. The hybrid strategy is used to gain insight from the audience through questions and talking with them and as well to help the artist understand his public, their motives and expectations.

The marketing mix is straight forward, emphasizing especially on cost of production and logistics in order to generate profits. Every action that the artist and the management team do are focused on customer experience and satisfaction. The team that surrounds the artist are professionals with backgrounds from marketing, event management, public relations and sales. The suppliers used for outdoor posters and selling tickets are trustworthy, their services being standardized and always with a great respect for the customers and the image of the artist.

\section{Engagement}

The artist engages with his public mostly through social media. The communication is made with the help of the team public relations officer by press releases and social media (Facebook).

The social media platform mostly used by the artist is Facebook because it is easy to use, he can upload videos and music whenever he wants and campaigns are very easily managed from here. The way in which the target works on Facebook is very straight forward with selecting the target audience, age, sex, location, interests, education, career level and even income. 


\section{Event promotion}

For the month December we documented campaigns done for the promotion of one concert. The $10^{\text {th }}$ of December 2018 benefited from three major directions of promotion.

First of all, the promotion started on the first of November. The artist went on TV and on radio to promote his concerts in order to attract more than just his core public.

Second, the artist started to tease about the third consecutive concert in three years that will take place at the end of the month, near Christmas. The artist taught his public with having a carols concert for Christmas so that they will crave it. The artist created a need for his public, a need that maybe they did not have. In this way, they will pay the emotional price of the ticket which is higher than the first edition.

Third, a budget of roughly 300 euros has been established for promotion on Facebook. The four campaigns that worked for one month and ten days managed to reach over 60.000 people. The event was a success and sold full house. The location at University Square, in a place that has easy access to parking so that people will feel ok if they wanted to drive to the venue. There are over 15.000 likes on his artist page and more than 10.000 in groups and on his private account so the reach is very high especially for Bucharest.

Word of mouth is very important for the artist and his shows.

\section{Methodology}

We surveyed latest articles in the creative industries and service marketing domain in order to extract the most important trends and realize connections between these trends and sets of data.

We analyzed the quantitative data offered by the National Institute of Statistics in Romania and Eurostat to see differences between other European states and finally to see the internal evolution of the performing arts in Romania.

The data has been analyzed with the help of cultural marketing theory and creative industries best practices.

For the case study we discussed about an artist in Romania that had an event on the $10^{\text {th }}$ of December. We had access to empirical data related to his marketing efforts. As well, we had access to his private page information through the help of his management team. The management team did agree to lend us some quantitative and qualitative information throughout a discussion, but did not offer the exact data for us to publish because of GDPR and confidential information reasons.

\section{Results and discussions}

We can see that the performing arts industry is growing in Romania by the data offered by INS. As well, from the Eurostat data we can see a positive trend in the creative industries overall. The theater services and concerts are booming in Romania.

Although the cultural services are rising in number of spectators, it is rather interesting to see that no new plays or concerts of festivals appear. We have a large population that is interested in participating in creative events, but there are not enough.

Another interesting subject is to see and understand how artists see their public. How do they interact with them? What would they want more from their relationship with their public? Do they feel that their art is subject to discussion with the public? Or not? 
These questions are very good even for our case study, we tried to discuss this with the artist and he said that "My music is received from somewhere for everybody. I would love to talk about music with my public, I would love to hear their opinion on everything, I would love to be able to thank everybody with my music, but it is not possible. I have people with whom I discuss subjects, ideas and music so that I am closer to my public's needs."

\section{Conclusion}

It is very important to know the market that you address. In the performing arts industry it is vital to know the public because it can make or break your service. The artists that offer the service are very important as well, and their opinion about the way in which the service will be presented is crucial.

One conclusion is that it is good to know that the service will vary and it will never be the same. It is a service. But one thing that will never change is the journey the public is on and the way they feel after. Only that moment in which the artists interact in front of the public is known as "art". It is very important for artists to strive for a good feedback from their public. It is important as well to have in mind the opinions and needs of the public. Art is made with the help of the public, otherwise it would be just a service.

A second conclusion is that it is very important for artists to go digital to promote their art. It is a new way of creating and of engaging with other artists from around the world. The fact that the creative industries are developing in Romania means an opportunity for all artists in Romania to become a part of this global artistic movement. Romania has a large cultural, folkloric and traditional baggage that they can offer to the world. It is important to know that artists can promote their own view of traditional elements.

\section{References}

Blythe, J., 2005, Essentials of Marketing - Third Edition, Prentice Hall, Essex

Chaffey, D. and Ellis-Chadwick, F., 2016, Digital Marketing, Pearson, London, pp. 206-283

Eurostat (2018), Guide to Eurostat Culture statistics 2018, Luxembourg Publications Office of the European Union, Belgium

Flories, A., Perez S. and Blanc, F., 2010, El marketing de la cultura y las artes: una evolucion, Revista Nacional e Administracion 1(1), pp. 23-36

Galloway, S. and Dunlop, S., 2007, A critique of definitions of the cultural and creative industries in public policy, International Journal of Cultural Policy, Vol. 13, No1, pp. 1821

Groene, F. and Acker, 0., 2015, The digital future of creative Europe - The impact of digitization and the internet on the creative industries in Europe, pwc, New York, pp 6 $-20$

Iagăr, M., Ioniță, A., Rădoi, S., Ioța B., Negru, V., Baboi, V., Chiorean, S., 2016, Activitatea Unităților Cultural-Artistice pentru anul 2015, Institutul Național de Statistică, București, pp. 16-18

Iagăr, M., Ioniță, A., Rădoi, S., Iota, B., Constantinesu, A., Chindriș, G., Chiorean, S., 2017, Activitatea Unităților Cultural-Artistie pentru anul 2016, Institutul Național de Statistică, București, pp. 16-18

Institutul Național de Statistică, 2018, Comunicat de presă nr. 164/29 iunie 2018, INS Statistica Culturii, București, p. 2 
Jimenez, A. and Gervilla, M., 2011, Manual de marketing y comunicacion cultural, Universidad de Cadiz, Cadiz, p 140-142

Kotler, P. (2011). Reinventing Marketing to Manage the Environmental Imperative, Journal of Marketing

Kotler, P. and Armstrong, G., Opresnik, O., 2017, Principles of Marketing, Pearson, Harlow, p 200-220

PICBE $\mid 226$

Keegan, J. and Green, M., 2016, Global Marketing, Pearson Education Limited, Essex, pp 493494

Klamer, A., 1996, The Value of Culure - On the relationship between economics and arts, Amsterdam University Press, Amsterdam, pp. 45-46

Klamer, A., 2016, The value-based approach to cultural economics, Springer Science + Business Media, New York, pp. 4-6

Mucică, D., Becuț, A., Bălșan, B., Croitoru, C., Ionică, P., Nițulescu, V., Oprea, A., 2014, Strategia Sectorială în Domeniul Culturii și Patrimoniului Național pentru perioada 2014-2020, Centrul de Cercetare și Consultanță în Domeniul Culturii, pp. 31-40

United Nations Educational, Scientific and Cultural Organization (2017), Reshaping cultural policies - Advancing creativity for development 2018, Paris, France

Vickery, J., 2015, Researching SPILLOVER in the creative and cultural industries, Center for Cultural Policy Studies University of Warwick, pp. 2-8

Rizzo, I. and Tose, R., 2015, In memoriam Alan Peacock: a pioneer in cultural economics, Springer Science + Business Media, pp. 225-238

Scheff, J \& Kotler, P., 1996, Crisis in the arts: The marketing response, California Management Review Vol. 39, pp. 30-50

Thorsby, D., 2010, The Economics of Cultural Policy, Cambridge University Press, New York, pp. $20-50$ 